\title{
CRISTIANISMO E MARXISMO EM ESTAÇÃO, DE NUNO BRAGANÇA
}

\author{
La Salette Loureiro \\ (Universidade Nova de Lisboa) ${ }^{1}$
}

\section{RESUMO}

O escritor Nuno Bragança integrou o grupo de "católicos progressistas" que durante o regime de Salazar se empenhou na resistência à ditadura, através de várias formas de luta. $\mathrm{O}$ autor e as suas personagens literárias fundam a sua acção na prática dos valores autênticos do Cristianismo, nos quais encontram coincidências com alguns dos que são defendidos pelo Marxismo. Uma tal atitude implica, não raras vezes, uma crítica explícita ou velada à Igreja Católica oficial. No livro de contos Estação, encontramos a representação das diferentes classes sociais e das suas relações, numa perspectiva evolutiva, bem como os comportamentos reais, desejados ou desejáveis, de estruturas a quem são acometidas responsabilidades no funcionamento de uma sociedade que se pretende justa.

PALAVRAS-CHAVE: Nuno Bragança, Cristianismo, Marxismo.

\section{ABSTRACT}

The writer Nuno Bragança joined the group of "progressive Catholics" who during the Salazar regime engaged in resistance to the dictatorship, through various forms of struggle. The author and his literary characters base their action on the practice of authentic Christian values, some of which coincide with the ones defended by Marxism. Such an attitude often implies explicit or veiled criticism of the official Catholic Church. In the storybook Estação, we find the representation of different social classes and their relationships, in an evolutionary perspective, as well as a real, desired or desirable behavior of structures responsible for the functioning of a society we want fair.

KEYWORDS: Nuno Bragança, Christianity, Marxism. 
Como homem, continuo a ser um cristão que entende que certos valores do cristianismo passam por uma alteração profunda da sociedade e que a chamada luta de classes dá sinal de muito dessa direcção. (BRAGANÇA, 1978a)

A relação da obra literária de Nuno Bragança com a política é intensa e indiscutível, desde o seu primeiro romance, A Noite e o Riso, publicado em 1969. Neste romance, o protagonista sai do país porque o considera um "Portugal-prisão", numa clara referência à ditadura de Salazar e à falta de liberdade existente. Várias passagens abordam problemas relativos às diferentes classes sociais, apontando para os privilégios de uns e as carências e injustiças de outros. Nos romances seguintes, Directa, de 1977, e Square Tolstoi, de 1981, a acção principal dos protagonistas é exactamente a luta política, a resistência à ditadura.

Todos estes casos são de cariz autobiográfico, pois o autor, como as suas personagens, desenvolveu várias acções de resistência durante muitos anos, algumas de alto risco. Fazia-o por um imperativo ético, prejudicando a sua actividade de escritor e a sua vida pessoal e familiar, porque era incapaz de permanecer quieto e indiferente enquanto os seus irmãos eram explorados e maltratados, como revela em entrevista (BRAGANÇA, 1981) e as suas personagens confirmam nos seus livros.

Entretanto, para o autor, as formas de luta incluem também a escrita literária, tanto através de aspectos formais como através do seu conteúdo. Em primeiro lugar, porque a literatura é em si própria uma forma de revolução, já que, segundo o autor, "O escritor é necessariamente um revolucionário da forma. Mas como para mim não há forma e conteúdo separados, é tudo a mesma coisa, se o escritor revoluciona a escrita necessariamente está apanhado num processo de transformação." (BRAGANÇA, 1981). Em segundo lugar, porque as suas atitudes revelam a sua convicção de que o conteúdo dos seus romances teria um impacto mobilizador junto do público, como prova a intenção de introduzir clandestinamente em Portugal o livro que viria a ser Directa. Se esta intenção não se confirmou, já que o livro foi concluído e publicado já depois do 25 de Abril, algo de semelhante aconteceu em Agosto de 1975, pois Nuno Bragança publica n’O Jornal, números 14 a 17, um longo texto intitulado "O Discurso de Leonardo", apresentando-o como um excerto deste romance, com o objectivo de impedir uma guerra civil entre os portugueses, oferecendo-lhe um "contributo para uma leitura em profundidade dos actuais acontecimentos políticos em curso de crise", ${ }^{2}$ como diz num texto introdutório.

Com esta conviç̧ão, Bragança aproxima-se do pensamento de Julia Kristeva, quando esta considera como "la fonction sociale des textes: produire un sujet différent, susceptible d'induire de nouveaux rapports sociaux, et s'inscrivant ainsi dans le processus de subversion du capitalisme" (KRISTEVA, 1974, p. 100). Está também em sintonia com Paul Ricoeur, para quem "O mundo do texto, porque é mundo, entra necessariamente 
em colisão com o mundo real, para o "refazer", quer o confirme quer o recuse" e, assim, "seria incompreensível se a arte não des-arrumasse e não re-organizasse a nossa relação com o real” (RICOEUR, 1989, p. 29-30). Quer isto dizer que "narrative representation - story-telling - is a historical and a political act." (HUTCHEON, 1995, p. 51).

$\mathrm{Na}$ luta do autor e das suas personagens, destacam-se dois horizontes mobilizadores e aparentemente antagónicos: o cristianismo e o marxismo. O primeiro recebeu-o o autor por educação, mas aprofundou-o por opção como adulto, individualmente e em grupo, nos chamados "católicos progressistas", nomeadamente através da colaboração em órgãos de comunicação de raiz católica, como foram o jornal Encontro, da Juventude Universitária Católica (JUC), fundado em 1956, e depois a revista O Tempo e o Modo, de que foi co-fundador e colaborador desde o primeiro número, em 1963. Uma outra experiência relevante é a sua participação no Cineclube Católico, em que colaborou com a programação e críticas de filmes de reconhecida qualidade.

O segundo horizonte que mencionámos, o marxismo, teria inevitavelmente de encontrá-lo na sua actividade política, mas ele é também objecto de reflexão nas páginas da revista O Tempo e o Modo e em outros órgãos de comunicação da época. Para além disso, sobretudo a partir da década de 60, a Igreja Católica é obrigada a confrontar-se com a doutrina marxista, nomeadamente a partir da publicação da Encíclica Pacem in Terris, de João XXIII, em 1963, durante o Concílio Vaticano II, que, segundo Nuno Bragança, "lançou os alicerces de uma redescoberta do que seja a Igreja de Cristo" (BRAGANÇA, 1981). Paralelamente, na mesma época desenvolve-se na América Latina o movimento denominado "Teologia da Libertação", que vem questionar o comportamento da Igreja Católica, principalmente no que respeita às suas ligações com o poder e o tratamento que dispensa aos mais desfavorecidos. Vários testemunhos mostram que Nuno Bragança se revê tanto nas ideias do papa João XXIII como no movimento acima referido.

Em entrevista de 1977, o autor faz uma síntese do seu posicionamento relativamente ao cristianismo e ao marxismo, dizendo o seguinte:

NB - Pela minha parte, eu estava empenhado numa luta como cristão, com uma determinada visão do mundo, que ainda continua a ser a minha, a qual exigia um mínimo de liberdades - que não existiam então - e que fossem dados passos concretos no sentido de uma redistribuição de bens e um ajuizar dos valores prioritários que deviam orientar a actividade em Portugal.

- Essa visão é a que se encontraria em qualquer encíclica de um papa decente... Era portanto a chamada luta por "uma sociedade mais justa"?

NB - Essa "sociedade mais justa" das encíclicas surge condicionada pelo mundo capitalista em que as próprias encíclicas 
se integravam, e tentavam salvaguardar. (Excepto a Pacem in Terris em que João XXIII apontou para uma sociedade inteiramente diferente). Elas eram para mim um valor referencial, mas toda a análise marxista - que não tinha sido aceite pela Igreja Católica - valia para mim, como reflexão a ter em conta na construção de uma sociedade diferente. Portanto, creio que estava mais à frente desse conceito de "sociedade mais justa", e que a minha posição era então declaradamente de esquerda, como continua a ser.

\section{- De esquerda marxista?}

NB - Não que para mim o marxismo seja a última descoberta da verdade do homem, mas encaro-o como um passo importante para a descoberta de factores que condicionam a existência do homem. (BRAGANÇA, 1977)

São estas duas bússolas, cristianismo e marxismo, que orientam a acção do protagonista do seu segundo romance, Directa, publicado em 1977, mas escrito, segundo o autor, sobretudo no início dos anos 70, em Paris. No romance, fica muito clara a intenção de transmitir ao leitor essas duas orientações que enquadram a sua luta e o seu viver. Primeiro porque, antes de sair de casa, o herói procura e lê "o texto necessário para se fortificar naquela madrugada”, um texto da Bíblia, do Livro de Isaías, de cuja transcrição destacamos a seguinte passagem:

Sabeis qual é o jejum que eu aprecio - diz o senhor Deus:

É romper as ligaduras da iniquidade, desatar os nós do jugo, deixar ir livres os oprimidos e quebrar toda a espécie de jugo; é repartir o seu pão com o esfomeado, dar abrigo aos infelizes sem asilo, vestir o nu, e não desprezar o teu irmão. (BRAGANÇA, 1995, p. 23)

O excerto que aqui transcrevemos e toda a passagem transcrita no romance revelam, a nosso ver, a intenção de clarificar o seu entendimento do que é o cristianismo, "o convite que a vida faz ao homem para que desenvolva a sua estatura de pessoa devotando-se ao serviço de todos" (BRAGANÇA, 1964), portanto, distante das práticas da Igreja Católica institucional. Neste sentido, esta escolha representa, por um lado, uma indicação de como deve ser vivido o verdadeiro cristianismo, por outro, constitui uma severa crítica ao comportamento da instituição católica, ao mesmo tempo que revela uma aproximação aos ideais defendidos pelo marxismo.

É esta segunda bússola que surge enunciada no final do romance, onde, já numa narração de primeira pessoa, o protagonista afirma:

Historicamente, eu tinha uma ligação fortíssima a Outubro 1917. E quantos erros e distorções eu vinha identificando nesse parto, maior a minha convicção de que a Rússia tinha dado à luz alguma nubelosidade na treva cheia em que o mundo andava mergulhado. (BRAGANÇA, 1995, p. 250) 
Por aqui se vê que Nuno Bragança e as suas personagens encontram um elo entre estas duas doutrinas, se assim se podem chamar. Estes dados permitem-nos perceber melhor o livro de contos do autor intitulado Estação, nomeadamente o conto com o mesmo nome.

O livro Estação, publicado em $1984,{ }^{3}$ engloba cinco contos, sendo três inéditos e dois já publicados anteriormente. Com excepção de "A Tia de Inglaterra", conto escrito por encomenda para o livro Poética dos Cinco Sentidos. La Dame à la Licorne, ${ }^{4}$ em que o autor escreve sobre o Gosto, todos os restantes focam o tema das classes sociais e suas relações, sobretudo da classe dominante e da classe dominada, aproximando-se assim da temática neorrealista, corrente pela qual o autor diz ter muito respeito. $\mathrm{O}$ desejo de ascensão social, expresso frequentemente pela expressão "querer ser alguém”, surge várias vezes, através de algumas personagens que, de diversas formas e por diferentes razões, procuram aceder a um estatuto social superior. Espantosamente, também o desejo de passar para o lado da classe inferior surge num dos contos, o que leva a um desenlace que não deixa de surpreender o leitor.

As palavras cristianismo e marxismo nunca aparecem, mas estes conceitos e o seu significado estão implícitos nos temas escolhidos e na abordagem que é feita, que torna visível a presença ou a ausência dos valores que norteiam uma e outra "doutrina”.

A sequencialização dos contos - "O Imitador", "A Navalhada", "Uma Despedida", "A Tia de Inglaterra" e "Estação" - parece não ter sido feita de modo aleatório, ela ganha um sentido histórico, correspondente a uma caminhada que se orienta numa determinada direcção, a direcção da História, das classes sociais e suas relações, mas também da evolução do trabalho, desde o manual até ao intelectual, permitindo mostrar muito especialmente as condições de vida dos trabalhadores e dos pobres.

No final, o último conto, "Estação", surge como um momento de reflexão e avaliação, um acerto de contas com a História, uma paragem de e para meditação, como em cada estação da Via-Sacra.

Como é sabido, o primeiro e o último contos ocupam lugares estratégicos e não será por acaso que neles surgem referências às doutrinas mencionadas, de forma directa ou indirecta. Como escreve Iuri Lotman, "O limite, mostrando ao leitor que ele trabalha com um texto e chamando à sua consciência todo o sistema dos códigos artísticos correspondentes, encontra-se estruturalmente numa posição forte." (LOTMAN, 1978, p. 105)

A nossa análise não pode deixar de fora uma breve reflexão sobre a palavra que dá nome ao livro e a um dos contos, "Estação", pela importância que ela assume neste contexto. O conto com este título, pelo lugar estratégico que ocupa, ganha um particular relevo, que é obviamente ampliado pelo facto de o nome surgir logo na capa, e permanecer, por isso, na memória do leitor ao longo da leitura do livro. 
Entretanto, os leitores de Nuno Bragança dificilmente estranharão este destaque, dada a frequência com que a palavra "estação" ocorre na sua obra. De facto, este vocábulo aparece muitas vezes no primeiro romance, associado à viagem de comboio, em sentido próprio e simbólico. $\mathrm{O}$ herói é captado a entrar ou a sair da estação de comboio e essas situações representam o fim ou o princípio de etapas da evolução do protagonista, que significam para este a aquisição de aprendizagens e autoconhecimento indispensáveis à construção do seu "eu verdadeiro". As estações de comboio de Lisboa, de Belgrado ou de Zagreb representam ou representarão efectivamente marcos sucessivos e diferentes estádios da construção do eu do herói.

Já em Directa, na "Nota do autor para o leitor" que acompanha a primeira edição, o autor atribui a esta palavra um sentido espácio-temporal, mas com ressonâncias religiosas, que a aproximam da paixão de Cristo revivida na Via-Sacra, ao afirmar o seguinte: "Ao publicar Directa, sei que isso representa uma estação, que em meu viver ultrapassa a mera escrita. Faço-o consciente de que há grande caminhada que me falta ainda percorrer." Por aqui se vê que a palavra assume um valor de espaço-tempo, no aqui-agora de uma pessoa, um recorte temporal de quem está em trânsito, não um lugar de paragem para ficar, mas um lugar de passagem e paragem para reflectir e progredir no caminho que está em curso.

No livro de contos, o facto de a palavra "estação" surgir nos títulos sem qualquer determinante dificulta ao leitor a selecção de um significado preciso e mantém-no em suspense ao longo da leitura dos vários contos, pois é só o último que ganha este título e só mesmo no seu final esta palavra aparece. Ela aparece algumas vezes no conto "Uma Despedida", associada ao metropolitano em que viajam normalmente as personagens, não assumindo, por isso, um relevo que justifique o título do livro.

Assim, o leitor é obrigado a efectuar um longo percurso para atingir o que almeja desde o contacto com a capa do livro, mas será a realização dessa caminhada que o preparará para melhor entender de que "estação" se trata, afinal, ou seja, ele é obrigado a percorrer várias "estações", as que correspondem à história das relações dos patrões/senhores com os trabalhadores, para aceder a esta derradeira "Estação", o que lhe permite articulá-la com a expressão e o significado da "Via Sacra".

Se seguir a linearidade do livro, o leitor começa por atravessar o conto "O Imitador", 5 que estabelece como que o ponto de partida da "análise" das relações entre a classe dominante e a classe dominada, entre senhores e trabalhadores. Paralelamente, ele estabelece um contraponto com o último conto, "Estação", não porque esta palavra apareça, mas porque outras a tornam implícita, como são as referências ao "calvário" (BRAGANÇA, 1997, p. 36) e aos "pretorianos" (BRAGANÇA, 1997, p. 39), que estabelecem um paralelo com a paixão de Cristo, comemorada nas "estações" da Via-Sacra, que assume um valor fundamental no último conto. Ao con- 
siderar-se o "calvário" infligido a Cidre, de algum modo está a associar-se o seu sofrimento ao que Cristo sofreu durante a Paixão e Crucificação. Já a instituição Igreja é subtilmente associada ao seu algoz, ao poderoso António Vianna, quando se diz que "Obedecendo a um instinto de conservação digno de qualquer Igreja multissecular, António prosseguia uma política de transferência parcial de capitais, do campo para a Cidade." (BRAGANÇA, 1997, p. 34).

Por outro lado, ao considerar-se a personagem principal, Cidre, como uma "espécie de Elias negativo" (BRAGANÇA, 1997, p. 14), aponta-se também para o último conto, onde surge a evocação do profeta Elias pela personagem Padre Mendes. Este paralelo convoca interpretações não despiciendas no contexto do livro e dentro da temática que aqui analisamos. Enquanto "negativo" do profeta Elias, Cidre não só desconhece os ataques dos seus perseguidores e inimigos que o esperam no futuro, como se encontra totalmente desprotegido, sozinho, enquanto o Elias bíblico tinha garantida a protecção de Javé, facto que ocorre à personagem do último conto quando, numa situação de aperto, o evoca. A nosso ver, esta ausência da protecção de Deus a Cidre sinaliza as falhas da Igreja Católica relativamente aos mais pobres e mais desprotegidos, questão que estará em análise no conto "Estação", como veremos.

O protagonista deste conto desempenha as funções indicadas no título e é levado para a herdade dos Viannas, onde permanece para servir de uma espécie de bobo da corte, para divertir os senhores e a população, um tipo de profissão superior à dos jornaleiros que trabalham os campos. É ao longo da sua acção, que corre em paralelo com a do narrador-personagem, que se constroem os sentidos mais importantes deste conto. Sendo o mais longo de todos, ele relata uma história passada no campo, pondo em cena a classe social superior, ainda aristocrática e rural, e a classe inferior, campesina, e mostrando a miséria e a exploração a que a segunda é submetida, com alguma colaboração da própria, porque, por um lado, "A posição dos Viannas versus bimbos da gleba era sobretudo forte graças ao jogo de uma vigarice muito antiga: o campesinato mostrava-se sensível ao brilho humano de um campeão" (BRAGANÇA, 1997, p. 30), por outro, porque os camponeses viviam "embrutecidos pela rotineira alienação de fôlego e músculos" (BRAGANÇA, 1997, p. 21), um facto que aflora algumas vezes na obra de Bragança. A alienação pela dureza do trabalho e das condições de vida é, como se sabe, um tema caro ao marxismo.

As duas razões acima mencionadas estarão na base da participação dos camponeses, ao serviço dos senhores, em práticas de uma brutalidade de "grau inaceitável" sobre Cidre, o imitador, práticas que o narrador-personagem associa às do campo de concentração de Dachau (BRAGANÇA, 1997, p. 26). Trata-se do momento em que "António e os seus amigos, abandonando inexplicavelmente a brutalização directa, tinham encarregado alguns criados de o ferir" (BRAGANÇA, 1997, p. 39). 
As performances de Cidre descritas no conto fazem lembrar as técnicas do Living Theater, que o autor conhece bem. A relação que o imitador desenvolve com António, que se torna uma espécie de autor e encenador das suas partes leva a que Cidre acabe por pertencer-lhe "como se fosse simultaneamente discípulo, escravo, coisa, amigo, esposa e perdigueiro." (BRAGANÇA, 1997, p. 22), uma relação de posse e submissão que atinge o seu auge quando lhe são "negados os mais elementares dos direitos naturais” (BRAGANÇA, 1997, p. 23), sem que aquele reagisse. Mas um dia António vai mais longe, quando chega à "descoberta de que a crueldade era o mais seguro dos caminhos curtos” (BRAGANÇA, 1997, p. 24) e orienta a "carreira" do seu "artista" para a sua autodestruição. Cidre, no apogeu da sua alienação, causada pela convicção de que "cada dia era mais artista" (BRAGANÇA, 1997, p. 25), quando já entrava em declínio, e pela ilusão de ascensão social, não se dá conta do abismo que o espera, corre em direcção a ele, insensível a humilhações e flagelações, até à estocada final.

É neste contexto que surge o caso que merece do narrador a designação de "calvário" (BRAGANÇA, 1997, p. 36), a que Cidre é submetido, tanto pelo seu "dono", António Vianna, como pelos camponeses, situação para a qual se encaminhou ao aceitar ser levado para a herdade $A$ Trovisca, "confuso de surpresa e carrascão, sem suspeitar do que lhe estava reservado, espécie de Elias negativo” (BRAGANÇA, 1997, p. 14).

Este paralelo com o calvário inclui o gáudio, a insensibilidade, o prazer sádico perante o sofrimento do semelhante, "uma demonstração prática do que consegue a habituação à indiferença pelas emoções de quem respira a nosso lado" (BRAGANÇA, 1997, p. 36), manifestados por António, mas também pela assistência, mostrando como estas características negativas não afectam apenas os ricos, a classe dominante, mas são inerentes ao ser humano, naquilo que este tem de pior e é aqui denunciado.

O relato da desgraça de Cidre cruza-se com o relato do infortúnio do narrador-personagem, quando, ao tentar libertar-se dos seus carrascos, Cidre envolve o segundo na sua humilhação, frustrando-lhe as aspirações de ser "alguém", que projectara realizar através do casamento com a herdeira da família. Tal objectivo não se concretizou, porque, como o próprio reconhece, "os fados se encarregaram de aproximar as nossas humilhações, como facas cruzadas sobre a mesa de uma refeição implacavelmente votada a insucesso desairoso." (BRAGANÇA, 1997, p. 36). E assim é levado a reconhecer que "a carreira que escolhera" era "a de imitador do ser Vianna" (BRAGANÇA, 1997, p. 42), portanto, uma versão amadora do "imitador" profissional. Qual dos dois dá o título ao conto é uma questão que terá de ser o leitor a decidir.

A localização temporal da acção não é referida no texto, há no entanto pontos de referência que nos permitem considerar os factos narrados como anacrónicos, que ocorrem "apesar da História” (BRAGANÇA, 1997, p. 32). 
No segundo conto do livro, intitulado "A Navalhada", verifica-se um grande avanço na História, manifestado num tipo de trabalho que já é fabril, numa escala de exploração ao nível dos diferentes países europeus, entre aqueles que são ricos e aqueles que são pobres, num modelo de sociedade capitalista, que, segundo Nuno Bragança, "é um sistema socio-económico cujo objectivo não é a melhoria das condições de vida dos humanos, mas o lucro" (BRAGANÇA, 1978b, p. 36). A diferença mais significativa, todavia, revela-se na consciência dos direitos dos trabalhadores, que, em situações de injustiça, ousam reclamá-los e exigi-los, o que representa uma assimilação da lição de Marx.

Poder-se-ia dizer que, devido às condições de vida dos camponeses que vimos em "O Imitador" e às condições políticas geradas pela ditadura de Salazar, estes se transferiram para o estrangeiro. O conto trata, portanto, da emigração, um tema que Nuno Bragança, à época alto funcionário da OCDE, em Paris, conhece muito bem e aborda também no documentário Nacionalidade: Português, de 1973. Este documentário, de cuja rodagem e montagem se dá conta no romance Square Tolstoi, trata das condições de vida e de trabalho dos emigrantes portugueses em França, nos anos 70, tal como acontece no conto. Nuno Bragança é simultaneamente produtor e autor do texto e ainda participa com Fernando Lopes na realização e montagem do filme, de que, segundo José Navarro de Andrade, é o mentor.

No conto, o protagonista, alentejano, chegado a França em 1970, junta-se a estremenhos, algarvios e beirões, "a fragmentação da portugalidade" (BRAGANÇA, 1997, p. 51), que mostra a sangria a que o país foi submetido, por razões económicas e políticas. Aqui, a dicotomia classes ricas/ classes pobres alarga-se para a dicotomia países ricos/ países pobres. Como sublinha o narrador, "A Europa nova-rica estava apressadamente erguendo a sua fatal pirâmide de produto bruto, e os negreiros dela organizavam o afluxo de turcos, norte-africanos, jugoslavos, gregos, espanhóis, italianos, portugueses." (BRAGANÇA, 1997, p. 47). As más condições de vida continuam, no entanto, há uma tremenda evolução, como já se referiu, pois numa situação difícil, "Num relâmpago de inteligir, os emigrados perceberam que a serração dependia dos braços deles." (BRAGANÇA, 1997, p. 50). Assim, a consciência dos seus direitos e a descoberta do seu papel na cadeia de produção de riqueza conferem-lhes um poder que leva à opção pela greve para resolver uma situação de injustiça laboral. A greve fez-se e produziu os seus efeitos imediatos, mas o desfecho não é completamente perfeito. O chefe da rebelião, personagem principal do conto, foi denunciado ao superior, acusado de comunista, e é obrigado a afastar-se, mas há aqui um progresso significativo relativamente à situação vivida no primeiro conto. Entretanto, as condições para a exploração da classe inferior pela classe superior continuam, uma vez que, segundo o protagonista do conto, "Doença é a ignorância desse povo" (BRAGANÇA, 1997, p. 53), uma referência directa à atitude daqueles que se acobardaram e o denunciaram, por medo e ignorância dos seus poderes de classe. 
O terceiro conto do livro, "Uma Despedida", ocupa também um lugar estratégico, a posição central, equidistante do primeiro e do último, o quinto. Esse facto confere um valor simbólico especial a alguns acontecimentos narrados, como desenvolveremos mais à frente.

Este conto coloca o foco num tema que ocupa um grande espaço na ficção literária de Nuno Bragança e nas suas reflexões e se caracteriza por ser mais ou menos transversal à sociedade, embora do ponto de vista económico e social seja mais frequente na classe inferior. Trata-se do desejo de "ser alguém", já aqui referido, que, por influência da família e da sociedade, provoca desvios no percurso do ser humano relativamente ao seu ser verdadeiro, à sua vocação própria, infligindo-lhe sofrimento e infelicidade, que por sua vez irão gerar comportamentos nocivos ao próprio e aos outros. Sobre este assunto, em 1968, Nuno Bragança, ao responder a um inquérito, escreve o seguinte: "Ainda hoje envenenamos a alma da criança cortando-lhe as asas à imaginação para que aprenda a lutar para ser alguém. Como se a criança fosse inexistente, e a sua vocação diferente da de desabrochar em paz, à luz." (BRAGANÇA, 1968, p.145).

A perspectiva apresentada tem, como se vê, origem e consequências no viver social, já que é a sociedade que, por um lado, determina os padrões de sucesso ou insucesso pessoal, aqueles "que nos definirão como realizados ou falhados, como pessoas de valor ou pobres diabos apagados" (BRAGANÇA, 1968, p. 147), mas, por outro lado, é ela também a receptora dos malefícios que resultam do facto denunciado pelos "homens mais lúcidos", segundo os quais "a maior parte da humanidade vive presa, e morre ingloriamente aos bocadinhos" (BRAGANÇA, 1968, p. 148).

Constata-se, pois, que "a tal famosa realização de nós consiste antes do mais em aprendermos a estar à vontade sobre a terra" e em "escolher a actividade e o rumo que em cada etapa da nossa vida melhor nos permitam estar em forma e ser de utilidade" (BRAGANÇA, 1968, p. 148), resultando daí uma maior felicidade individual e do grupo.

A expressão "ser de utilidade" já remete para a relação do eu com o outro, no entanto, a aguda consciência da responsabilidade do indivíduo para com o destino do seu semelhante leva Nuno Bragança a ir mais longe na definição dos laços que os ligam, como se pode ler na transcrição que fazemos a seguir:

Dando em frente o passo necessário para compreendermos a nossa verdadeira dimensão, somos levados a escolher entre a estratégia para nos encaixarmos no lote privilegiado da sociedade ou para alinharmos na única tarefa digna de absorver o tempo e o esforço duma pessoa: a edificação de um corpo social que não deixe de fora uma só pessoa, de uma sociedade que sinta o problema de uma qualquer parte dela como qualquer indivíduo sente que uma unha encravada no pé esquerdo lhe afecta a pessoa toda. (BRAGANÇA, 1968, p. 148) 
As ideias aqui apresentadas enquadram-se, a nosso ver, tanto no cristianismo como no marxismo e explicarão a proximidade do autor relativamente a um e a outro.

Em nosso entender, este problema encontra-se equacionado e ficcionado no conto "Uma Despedida", que coloca em cena personagens de classes sociais diferentes, uma da classe inferior, procurando ser "ALGUÉM” (com todos os caracteres grafados a maiúsculas), e outra da classe superior, procurando a aceitação da parte dos da classe inferior e o encontro com "alguém" (com todos os caracteres grafados a minúsculas). Como se depreende do que já foi dito, o problema da realização pessoal cruza-se aqui com o tema das classes sociais, encontrando-se as personagens de uma e outra classe, curiosamente, em estado de frustração.

O conto começa com o casal Celina-Daniel, cujo casamento se apresenta claramente como insatisfatório, tanto a nível afectivo como sexual. Esta insatisfação é sentida e consciencializada sobretudo por Celina, já que Daniel se encontra obcecado e alienado pelo seu trabalho intelectual, relegando para segundo plano tudo o que não o conduzisse à sua almejada "ascensão". O narrador encarrega-se de pôr em destaque todo o seu projecto e as motivações que o determinaram:

Nascido de pais pobres em paupérrima Província, sentiu-se desde muito novo sôfrego de vir a ser aquele tipo de pessoa de quem a opinião geral afirma: "Este homem é ALGUÉM". E cedo pressentiu que o seu poder no campo racional seria o árduo mas fascinante trilho ascendente pelo qual treparia num alpinismo audaz até chegar ao cume onde se é ALGUÉM. (BRAGANÇA, 1997, p. 64)

Esta obsessão de Daniel leva-o a planificar toda a sua vida em função desse seu projecto, a ponto de se verificar que, segundo o narrador, "Daniel só despertava a valer quando um livro ou um colega de alto saber lhe permitiam os orgasmos do raciocínio." (BRAGANÇA, 1997, p. 64). Daniel vivia, assim, alienado pelo seu trabalho intelectual, ignorando até que não era feliz, quando o acaso lhe pregou uma partida. Trata-se do encontro com uma desconhecida nas estações e no comboio do metro, uma mulher de que emanava "um perfume forte, auréola do corpo" (BRAGANÇA, 1997, p. 65). O narrador não se coíbe de comentar esse encontro, procurando-lhe as origens e os efeitos, comentários que têm obviamente a ver com a vocação e a consequente realização de cada um.

O quotidiano de Daniel foi efectivamente abalado e tanto ele como o leitor são levados a imaginar uma determinada evolução desta história. No entanto, o desenvolvimento escolhido por Nuno Bragança e o seu narrador é deveras surpreendente e desconcertante para Daniel e para o leitor.

Para o tratamento do tema que aqui nos interessa, importa-nos destacar um facto que consideramos simbólico e revela uma evolução na História, não necessariamente real, mas seguramente desejável e enqua- 
drável nos desígnios de uma sociedade mais justa que vão sendo sugeridos ao longo do livro. Trata-se das viagens diárias dos protagonistas, Daniel e a Mulher-Espanto, no mesmo meio de transporte, o metro, o que representa uma aproximação das classes sociais, que parecia impossível no universo dos dois primeiros contos. $\mathrm{O}$ facto de esta convivência interclassista ocorrer no conto que ocupa o centro do livro, não nos parece indiferente na construção de sentidos. Ao contrário, este facto parece conferir um valor de centralidade a esta mensagem, que, a nosso ver, é confirmada pelos outros textos do livro.

Esta proximidade, como mostra o resto do conto, não representa, no entanto, a integração efectiva de um membro de uma classe na outra, como prova uma passagem da história contada pela desconhecida:

Quando eu era pequena a minha mãe bateu-me muito nos dois lados da cara. Porque eu estava descalça, num terreiro da Vila. A brincar com as descalçadas crianças do lado pobre.

Depois de ser batida fiquei sentada no chão a pensar nos dois lados da Vila. Eu vivia no lado que não era o lado pobre e não gostava das crianças engomadas.

No dia seguinte voltei ao lado pobre e pedi asilo. Mandaram-me embora e sempre até hoje acho que fiquei sem lado. (BRAGANÇA, 1997, p. 73)

De facto, esta história comovente mostra como a mobilidade social esbarra com incompreensões de um lado e de outro, deixando aquele que procura a integração numa "terra de ninguém", num lugar sem abrigo.

Quanto a Daniel, no seu projecto de ascensão social, agora à custa de sacrifícios próprios e sem envolver prejuízos de terceiros, como no primeiro conto do livro, esbarrou com a frase da desconhecida "É mau embarcar sem acenar a alguém." (BRAGANÇA, 1997, p. 77). Esta simples frase leva-o a constatar que "Do muito que o fazia sofrer num corpo desde sempre desprezado vinha ao de cima o caldeiro fervente da recordação do Projecto nutrido em muito novo: vir a ser ALGUÉM., onde se destacava aquela palavra para ele mágica, mas "tirando-lhe as maiúsculas. Tirando-lhe tudo." (BRAGANÇA, 1997, p. 77) Tal significa que os valores e objectivos de uma e outra personagem estão em clara dissonância.

O tema do corpo estabelece a relação entre este conto e os dois seguintes, de que, dado o assunto em análise, só abordaremos o último. Depois de ter apresentado contos correspondentes a épocas diferentes e a diferentes tipos de trabalho, manual, fabril, intelectual, como já dissemos, no último conto do livro, faz-se alegoricamente uma avaliação dos vários factores em jogo.

Aqui encontramos situações e personagens que, por sinédoque ou metonímia, representam estruturas com responsabilidade, pelo menos moral e ética, na organização e funcionamento da sociedade, oferecendo ao leitor uma oportunidade de análise e avaliação dos seus comportamen- 
tos relativamente às diferentes classes sociais em diferentes momentos da História. Por este motivo, este conto permite uma reavaliação retrospectiva de todas as histórias contadas até este momento. Ele permite perguntar: onde e com quem estava a Igreja Católica, quando os trabalhadores eram explorados, brutalizados e injustiçados? De que lado esteve o marxismo? Onde e com quem estava o poder político?

Com efeito, o cristianismo surge aqui como centro de "análise", colocando-se em questão a sua relação com os trabalhadores e com o marxismo e a sua relação com o poder político e o poder económico, tanto no presente como no passado, ou seja, nos tempos que alguns dos contos deste livro abordam.

Para esse efeito, temos uma situação triangular, com três personagens, um proleta louco, um sacerdote moribundo (Padre Mendes) e um Deputado-ex-Ministro, na qual se distinguem dois momentos. Sintomaticamente, a cena passa-se num hospital, lugar onde se tratam e curam os males e onde, frequentemente, muitos seres humanos atingem o final das suas vidas. A situação apresentada aponta para alguns erros e equívocos que a História regista e sugere comportamentos alternativos. Resumidamente, o Padre Mendes, em situação terminal, é atacado no seu quarto de hospital pelo proleta louco, que o quer matar devido a uma alegada traição. O primeiro vai tentando resistir e dissuadi-lo do seu intento, o que vai conseguir. Depois deste incidente, o Padre Mendes recebe a visita do Deputado-ex-Ministro, seu ex-aluno, que, perante os fragmentos balbuciados pelo primeiro, conclui que aquele "Já não sabe o que diz", apontando assim para a perda da razão.

A nosso ver, trata-se aqui de uma situação alegórica que representa a forma como o marxismo, aqui representado pelo proleta louco, se relacionou com o cristianismo, representado pelo Padre Mendes, e vice-versa. Posteriormente, representa-se a relação da Igreja com o poder, sendo este representado pelo Deputado-ex-Ministro. Porém não há aqui apenas uma representação realista da História, há efectivamente sugestões de alternativas a erros cometidos por ambas as partes.

A loucura do proletário e a acusação de traição ao padre aponta, a nosso ver, para duas questões; a primeira é a conhecida acusação de Marx feita no livro Crítica da filosofia do direito de Hegel, de 1844, segundo a qual "a religião é o ópio do povo", o que representará uma injustiça feita ao verdadeiro cristianismo; a segunda é o abandono a que a Igreja Católica votou os trabalhadores e os pobres, contrariamente à doutrina de Cristo, contida na Bíblia, o que representa também uma incompreensão do que é o marxismo, que ostensivamente se coloca, como Cristo, do lado daqueles. Esta crítica de Marx aponta, assim, para a alienação produzida pela religião, que impede que os trabalhadores tomem consciência da sua condição e dos seus direitos. Anos mais tarde, uma crítica semelhante será a resposta constituída pelo livro de Raymond Aron, intitulado O ópio dos intelectuais, 
em que o autor aponta para os erros e crimes provocados pelos regimes inspirados no marxismo e que não recebem a reprovação de intelectuais, alegadamente alienados pela ideologia de Marx.

Nesta tentativa de assassinato do padre pelo proletário será pertinente ver representada a tentativa do marxismo para fazer desaparecer o cristianismo, como aconteceu em países que adoptaram o regime comunista, que proibiram as práticas religiosas.

Verifica-se, entretanto, que o narrador mostra uma grande compreensão e simpatia para com estas duas personagens e chega a fazer paralelismos entre as suas condições de vida. Na verdade, ele começa logo por pôr em evidência a dureza das condições de vida do proletário, ao referir "as mãos calejadas por trabalho manual começado na infância" (BRAGANÇA, 1997, p. 93), mas dedica um grande parágrafo a explanar as condições de vida do padre, que, por imposição superior ou opção de vida, "Evitara o sexo, desprezara o prazer saudável da alimentação, a qual de resto, era quase sempre péssima. Trabalhara duramente em gabinetes sombrios, povoados de livros." (BRAGANÇA, 1997, p. 94). A reflexão termina pela referência a "um viver igualmente duro" (BRAGANÇA, 1997, p. 94) do proletário. Este paralelismo volta a surgir no texto, mas sobrelevando a situação-limite que o sacerdote está a viver, a hora da morte, que igualiza todos os seres humanos, portanto, destituindo-o do seu estatuto, do seu poder e dos seus privilégios: "Mas o Pe Mendes já não era Professor e Doutor, já era só ele, numa nudez de recém-nascido criado por Amor. Como o proleta louco." (BRAGANÇA, 1997, p. 97). Nesta afirmação encontramos os ensinamentos de Cristo e entrevemos uma crítica à Igreja Católica que combateu o marxismo, esquecendo que aquele decretou "amai-vos uns aos outros como Eu vos amei” (Bíblia Sagrada. Jo, 15,12, p. 1461). Neste contexto, como discorre o padre naquele momento de aflição, "ser assassinado por um louco era coisa de inscrever noutra Loucura: 'Amou-os até ao fim.” (BRAGANÇA, 1997, p. 97), ${ }^{6}$ isto é, a Loucura de Cristo que amou os seus até ao fim, mesmo aqueles que o traíram.

É seguindo este exemplo que o Pe Mendes nesta hora derradeira e "Com um esforço físico talvez derradeiro soltou o braço esquerdo e depôs a mão moribunda no ombro do homem que o queria matar." (BRAGANÇA, 1997, p. 97). Este gesto simbólico "corrige", a nosso ver, a atitude oficial da Igreja perante o marxismo, apontando ao mesmo tempo para a área política para que esta devia tender, a esquerda. Não é por acaso que a personagem que entra a seguir, o Deputado-ex-Ministro "percebeu que havia qualquer coisa fora do sítio: era o braço esquerdo que o sacerdote deixara pendente. O braço cuja mão afagara o ombro do proleta louco." (BRAGANÇA, 1997, p. 98). Ora este apontar para a esquerda, que pode ser a esquerda política, constitui uma correcção da trajectória que a instituição Igreja tem percorrido, como denuncia o autor, quando diz que "A Igreja Católica tem andado num vaivém terrível entre a fidelidade à 'Historia instituída por Cristo' e a História anticristã do Poder, do Dinheiro, da Guerra." (BRAGANÇA, 
1981). Verifica-se também uma inflexão na atitude do proletário, quando este aceita o gesto apaziguador do padre.

Neste sentido, o que se passa neste conto não reflecte a realidade tal como ela é, mas cruza-a com o desejo de como ela deveria ser, pois, no que concerne à relação entre o cristianismo e o marxismo,

Antes de João XXIII, os cristãos conscientes do carácter eminentemente anticristão do capitalismo tinham a vida dificultada porque a maioria do clero e a quase totalidade do episcopado só tinha olhos para os erros do marxismo, ignorando os propósitos de justiça que animaram a revolução de Outubro. (BRAGANÇA, 1978a)

A entrada em cena do Deputado-ex-Ministro marca o início do segundo momento da história e vem operar um volte-face, ao interromper uma sequência em que o padre se identifica com Cristo e com várias passagens do Evangelho e da Bíblia, e ao colocar em perspectiva o seu passado e a sua relação com o poder político e vice-versa, estando esta personagem obviamente a representar a instituição Igreja Católica.

A atitude da primeira parte é obviamente a que se espera de um padre, mas no conto fica a saber-se que o Deputado-ex-Ministro foi "um dos milhares de alunos que o Doutor Mendes ensinou na Faculdade" (BRAGANÇA, 1997, p. 98), o que mostra a relação da Igreja com o poder e a sua responsabilidade nas políticas adoptadas, quanto mais não seja porque, através do ensino, deveria fazer passar os valores de Cristo. Ora, o que os contos anteriores mostraram é que a prática do poder não segue os ensinamentos de Cristo, ou porque estes não são efectivamente transmitidos, ou porque são distorcidos por aqueles que os recebem. Neste caso, no conto, sugere-se a segunda hipótese, pois o Deputado-ex-Ministro de forma voluntária ou involuntária não percebeu a mensagem balbuciada pelo padre e distorce-lhe completamente o sentido, considerando que aquele já não está no seu juízo perfeito. Assim sendo, contrariamente às outras duas personagens, o representante do poder não manifesta qualquer intenção de mudança. No entanto, o padre deixa um aviso e conselho que, quanto a nós, constitui uma das mensagens fundamentais do conto, como nos deixa ver a articulação das palavras que a constituem com o título do conto e do livro.

A desvalorização feita pelo Deputado-ex-Ministro daquilo que o padre disse está em contradição com a opinião do narrador, para quem o padre, "No seu aparente divagar descia veloz ao centro da criação. 'Termos uma ideia ... Não, sabermos mesmo... qual é a nossa Estação.” (BRAGANÇA, 1997, p. 99). Nesta perspectiva, "Sabermos mesmo qual é a nossa Estação" é o imperativo que se coloca a cada ser humano e por maioria de razão às instituições, especialmente à Igreja. Tal significa que o Homem deve saber onde está em cada momento, ter em conta o aqui-agora com todos os seus condicionalismos, isto é, considerar "A vida na História", por- 
que, como diz o autor, "o homem é um ser inevitavelmente condicionado. É condicionado e tem que reconhecer que não poderá libertar-se senão através da identificação do estilo que os condicionalismos lhe impõem." (BRAGANÇA, 1968, p. 67). Ora, no aqui-agora da Igreja impunha-se-lhe conviver com o marxismo, como aliado, e não hostilizá-lo e combatê-lo, como inimigo.

No que se refere à deturpação da mensagem do Padre Mendes pelo Deputado-ex-Ministro, pode dizer-se que ela configura um paralelismo com o que, segundo o autor, se passava na realidade, em que os ricos interpretavam as palavras de Cristo de acordo com os seus interesses pessoais, deformando-lhes o sentido. E isto com a colaboração dos padres católicos (BRAGANÇA, 1978b).

Convém dizer que, quando Bragança fala em marxismo e na sua simpatia por esta ideologia, não padece da alienação de que fala o livro $O$ ópio dos intelectuais, já mencionado. Na verdade, o autor mostra ter ideias muito claras sobre esta matéria, baseadas em conhecimentos profundos da realidade histórica. Ele não confunde, por isso, os erros e as atrocidades cometidas por regimes comunistas com a doutrina de Marx e de Lenine, ele prova, pelo contrário, que essas atrocidades representam a negação e a deformação das ideias destes mentores (BRAGANÇA, 1978b).

Em suma, ao longo do livro Estação, constata-se que o autor constrói uma mensagem, a da defesa dos valores do verdadeiro cristianismo, o que implica uma atitude de vigilância relativamente às cúpulas da Igreja e ao exercício do poder. Segundo ele, estes valores aproximam-se em grande parte daqueles que são defendidos pelo marxismo, de onde resulta a sua adesão a esta doutrina, porque:

Quanto ao Evangelho, ou Boa Notícia (a notícia de que o Reino de Deus está entre nós, que temos acesso a ele) isso assinala uma igualdade e fraternidade de profundidades abissais, porque tem origem no Ser. A procura histórica duma estrutura política que se aproxime desta comunhão é um imperativo cristão. (BRAGANÇA, 1982).

Neste sentido, considera o autor, "em matéria de fecundidade, o cristianismo ainda tem umas palavras a dizer" (BRAGANÇA, 1964).

\section{REFERÊNCIAS BIBLIOGRÁFICAS}

ARON, Raymond. O ópio dos intelectuais. Coimbra: Coimbra Editora, 1980.

BÍBLIA SAGRADA. 3a ed. Lisboa: Paulus, 1997.

BRAGANÇA, Nuno. Algumas palavras a dizer. Vértice, Maio-Junho, 1964.

Directa. 3. ed. Lisboa: Publicações Dom Quixote, 1995. 
O Discurso de Leonardo. O Jornal, nºs 14-17. Lisboa, Agosto de 1975.

Entrevista de H. Vaz da Silva. Raiz \& Utopia, n. ${ }^{\circ}$ s 3.4. Lisboa: Liv. Bertrand, 1977.

Entrevista a O Jornal. O Jornal. Lisboa, 28-07-1978a.

Entrevista ao JL. JL, n. ${ }^{\circ}$ 35, 22 de agosto de 1982.

Entrevista de Mário Ventura. Diário de Notícias, 03 de maio de 1981.

Estação. 2. ed. Lisboa: Publicações Dom Quixote, 1997.

Inquérito. Cadernos O Tempo e o Modo, 3 - Deus o que é?. Lisboa: Moraes Editores, 1968.

Square Tolstoi. 2. ed. Lisboa: Publicações Dom Quixote, 1996.

A vida na História. Seara Nova, n. 1589. Lisboa, Março de 1978b.

HUTCHEON, Linda. The politics of postmodernism. London/ New York: Routledge, 1995.

KRISTEVA, Julia. La révolution du langage poétique. L’avant-garde à la fin du XIX siècle : Lautréamont et Mallarmé. Paris: Seuil, 1974.

LOTMAN, Iuri. A estrutura do texto artístico. Lisboa: Estampa, 1978.

MARX, Karl. Crítica da filosofia do direito de Hegel. 2. ed. Lisboa: Presença, 1983.

RICOEUR, Paul. Do Texto à Acção. Porto: Rés-Editora, 1989.

Recebido para publicação em 30/11/14

Aprovado em 22/01/15

\section{NOTAS}

1A autora fez mestrado e iniciou doutoramento nesta instituição

2 Nuno Bragança, O Jornal, n. 14-17, Lisboa, Agosto de 1975. O texto introdutório é parcialmente reproduzido na "Nota do autor para o leitor", que acompanha a primeira edição de Directa.

3 Estação, 1a edição. Lisboa: Assírio \& Alvim, 1984.

4 Nuno Bragança. Gosto. Poética dos Cinco Sentidos. La Dame à la Licorne. Lisboa: Livraria Bertrand, 1978, p. 36-44.

5 Conto publicado inicialmente na revista O Tempo e o Modo, n. ${ }^{\circ}$ s 54-55, Nov-Dez 1967. 6 Cf. Bíblia Sagrada. Jo, 13,1, p. 1458.

7 Título de texto de Nuno Bragança, publicado na revista Seara Nova. 